\section{THE NINTH JUBILEE OF GLASGOW UNIVERSITY.}

THE ninth jubilee of the University of Glasgow was celebrated last week with brilliant ceremony. The proceedings opened on Wednesday with a commemoration service in Glasgow Cathedral, when a sermon was preached by Dr. M'Adam Muir. In the afternoon Principal Story, the Vice-Chancellor, on taking the chair, read the following telegram from the King :- "I remember with what great pleasure I laid the foundation stone of your new buildings in 1866, and I heartily congratulate the University on the celebration of the 45 oth year of its existence." He then addressed a welcome to the delegates, who subsequently presented addresses from universities, colleges and other learned and public bodies on the Continent, in the United States of America, the British colonies and dependencies, and the United Kingdom.

The foreign institutions represented, in alphabetical order of countries, were as follows :-

Austria-Hungary: Universities of Cracow, Klausenburg, Lemberg, Prague and Vienna. Belgium: Free University of Brussels, Royal Academy of Science, Letters and Art, University of Liège, and Catholic University of Louvain. Finland: University of Helsingfors. France: Universities of Caen, Lille, Lyons, Aix.Marseilles, Montpellier, Paris and Rennes, Academy of Medicine, Institute of France, and Franco-Scottish Society. Germany: Universities of Breslau, Göttingen, Heidelberg, Kiel and Leipzig, and Royal Society of Sciences, Göttingen. Holland: Royal Academy of Sciences, and University of Utrecht. Italy. Universities of Bologna, Padua, Rome and Turin, Royal Academy of Sciences, Bologna, Royal Society of Naples, Italian Society of Science, Royal Academy of Sciences, Turin, and Royal Institute of Science, Letters and Art, Venice. Japan: University of Tokio. Norway: University of Christiania. Portugal: University of Coimbra. Russia: Universities of Kieff and Moscow, Imperial Society of Naturalists, and Imperial Military Academy of Medicine. Spain: University of Zaragoza. Sweden: Universities of Lund and Upsala. Switzerland: Universities of Bern, Geneva, Lausanne and Neuchatel. United States of America: University of Michigan, Johns Hopkins University, University of California, University of Boston, American Academy of Arts and Sciences, Massachusetts Historical Society, University of Chicago, University of Missouri, North-Western University, Dartmouth College, Cornell University, University of Wisconsin, Yale University, American Oriental Society, Columbia University, New York, Union Theological Seminary, New York, Leland Stanford Junior University, University of Pennsylvania, American Philosopical Society, Historical Society of Pennsylvania, Princeton University, Cooper Medical College, Columbian University, National Academy of Sciences, Smithsonian Institution, Clark University, American Philological Association, Archæological Institute of America, and Smith College.

The institutions in British Colonies and Dependencies represented at the celebration were :-

Australia: Universities of Adelaide, Melbourne and Sydney. Canada: Dalhousie University, Queen's College, Kingston, M'Gill University, and the University of Toronto. India: Universities of Allahabad, Bombay, Calcutta, Lahore (Punjab University) and Madras, and Asiatic Society of Bengal. New Zealand: University College, Auckland.

On the morning of Thursday there was a crowded attendance in the Bute Hall of the University to hear an oration on James Watt by Lord Kelvin, and another by Prof. Smart on Adam Smith, and to see the graduation ceremony at the conclusion of the addresses.

Lord Kelvin described Watt's career and achievements in an address of which the following is an abstract:-

The name of James Watt was famous throughout the whole world, in every part of which his great work had conferred NO. I 65 I, VOL. 64$]$ benefits on mankind in continually increasing volume up to the present day. It was fitting that the University of Glasgow, in this celebration of its ninth jubilee, should recollect with pride the privilege it happily exercised I45 years ago of lending a helping hand and giving a workshop within its walls to a young man of no University education, struggling to begin earning a livelihood as a mathematical instrument maker, in whom was then discovered something of the genius destined for such great things in the future. In a note by Watt appended to Prof. Robison's dissertation on steam engines, he said that his atten. tion was first directed in the year 1759 to the subject of steam engines by the late Dr. Robison, then a student in the University of Glasgow and nearly of his own age. He at that time threw out an idea of applying the power of the steam engine to the moving of wheel carriages and to other purposes, but the scheme was not matured, and was soon abandoned. On his going abroad about the year $176 \mathrm{I}$ or 1762 , Watt tried some experimen:s on the force of steam in a Papin's digester, and formed a species of steam engine by fixing upon it a syringe one-third of an inch diameter with a solid piston, and furnished also with a cock to admit the steam from the digester or shut it off at pleasure, as well as to open a communication from the inside of the syringe to the open air, by which the steam contained in the syringe might escape. That single acting, high-pressure syringe engine, made and experimented on by James Watt I 40 years ago in his Glasgow College workshop, now in 1901, with the addition of a surface condenser cooled by air to receive the waste steam and a pump to return the water thence to the boiler, constituted the common road motor, which, in the opinion of many good judges, was the most successful of all the different forms tried within the last few years. Watt left Glasgow in 1774 to live in the neighbourhood of Dr. Erasmus Darwin, grandfather of Charles Darwin. But Greenock and the University and City of Glasgow never lost James Watt. The University conferred the honorary degree of LL.D. upon him in 1806 . In 1808 he founded the Watt Prize in Glasgow College. He became Fellow of the Royal Society of Edinburgh in I784, Fellow of the Royal Society of London in 1785, correspondent of the French Academy of Sciences in 1808, one of the eight "Associés Etrangers" of the French Academy of Sciences in I814. Lord Kelvin did not know if any University in the world ever had a tradesman's workshop and saleshop within its walls, even for the making and selling of mathematical instruments, prior to 1757 . But whether the University of Glasgow was or was not unique in its beneficent infraction of usage in this respect, it was certainly unique in being the first British University-perhaps the first University in the world-to have an engineering school and professorship of engineering. This began under Prof. Lewis Gordon about I 843. Glasgow was certainly the first University to have a chemical teaching laboratory for students started by its first professor of chemistry, Thomas Thomson, some time between I 818 and 1830 . Glasgow was also certainly the first University to have a physical laboratory for the exercise and instruction of students' experimental work, which grew up with very imperfect appliances between 1846 and 1856 . Pioneer though it was in those three departments, it had been outstripped within the last ten or fifteen years by other Universities and colleges in the elaborate buildings and instruments now needed to work effectively for the increase of knowledge by experimental research and the practical instruction of students. But there was no lagging to-day in the resolution to improve to the utmost in all affairs of practical importance, and they almost saw attainment of the further aspirations to excel over all others in the magnificent James Watt Engineering Laboratory of the University of Glasgow to be ready for work before the expected meeting of the Engineering Congress next September. Now, through the magnificently generous kindness of $\mathrm{Mr}$. Andrew Carnegie to the people among whom he has made for himself a summer home in the land of his birth, all the four Scottish Universities could look forward to a largely increased power of benefiting the world by scientific research and by extending their teaching to young people chosen from every class of society as likely to be made better and happier and more useful to our country by University education.

The honorary degrees were afterwards conferred. The list was by far the longest that has ever been submitted at any graduation ceremony at the University. It included 22 Doctors of Divinity and no fewer than 120 
Doctors of Laws, including several ladies. This is the first instance of the bestowal by the University of honorary degrees upon ladies.

The new botanical department of the University was opened by Sir Joseph Hooker on Thursday in the presence of a distinguished company. Sir Joseph Hooker prefaced the ceremony with a description of the work done by his father both before and after he became professor of botany in the University in the first quarter of last century. He had not been educated for the medical, or, indeed, any other learned profession. Having inherited ample means and having been from childhood devoted to the study and collection of objects of natural history, he determined to devote his life and his fortune to travel and scientific pursuits. Early in 1820 , reduced circumstances requiring him to turn his botanical attainments to material account, he obtained, through the influence of his friend Sir Joseph Banks with George III., the chair of Regius Professor of Botany in this University. It was a bold venture for him to undertake so responsible an office, for he had never lectured, or even attended a course of lectures, and in Glasgow, as in all other Universities in the kingdom, the botanical chair was, and had always been, held by a graduate in medicine. Owing to these disqualifications his appointment was naturally unfavourably viewed by the medical faculty of the University. But he had resources that enabled him to overcome all obstacles-familiarity with his subject, devotion to its study, energy, eloquence, a commanding presence, with urbanity of manners, and, above all, the art of making the student love the science he taught. Continuing, Sir Joseph Hooker said :-

If I were asked what I regarded as of most importance to the student in the manner of my father's teaching I would answer that it taught the art of exact observation and reasoning therefrom, a schooling of inestimable value for the medical man, and one that is given in no other profession, but which ought to come, in this country, as it does in Germany, early in the education of every child. I have met many of my father's pupils abroad, in India and the Colcnies, who have told me that these botanical lectures gave them the first ideas they had ever entertained of there being a natural classification of the members of the vegetable kingdom. Then with regard to the results in a botanical point of view, the magnetism of the lecturer and the interest of the subject imbued many of his pupils with a love of science that proved permanent and fruitful. They made observations and collections for their quondam professor in the temperate and tropical climates of both hemispheres, some of them throughout their lives, which have very largely contributed to a knowledge of the flora and vegetable resources of the globe. After twenty years of professorship my father retired, and undertook the directorship of the Royal Gardens, Kew. Since that period great changes have been introduced in the method of botanical teaching in all our Universities, due, on the one hand, to a vastly advanced comprehension of the structure of plants and of the functions of their organs, and, on the other, to a recognition of the fact that the study of the animal and vegetable kingdoms cannot be considered apart. Furthermore, chemistry, physics and greatly improved microscopes are now necessary for the elucidation of the elementary problems of plant life. The instruction in these two sciences (chemistry and physics) has with all others advanced in this University pari passu with that of botany, and kept it in the forefront of the educational establishments of the kingdom. The addition of the building in which we are assembled is evidence of the resolve that it shall not relax its efforts to maintain its wellearned position, and with the conviction that the botanical laboratory will prove an invaluable aid to research under the æis of its distinguished director, I now, under his authority, declare it open.

The official celebration of the jubilee was brought to a close on Friday, when an oration on William Hunter, by Prof. Young, was read by Prof. Bower in the Bute Hall.

NO. I 65 I, VOL. 64$]$

\section{NOTES.}

THE late Prof. G. F. Fitzgerald was so highly esteemed in the world of science that a movement to establish a memorial of his greatness will certainly meet with ready and liberal support. It is proposed to found a "Fitzgerald Research Scholarship," to. be awarded annually at Trinity College, Dublin; and a large and influential committee of leaders of science at home and abroad has been formed to obtain funds for this purpose. The object is one which would have had the entire approval of Prof. Fitzgerald, whose chief care was the encouragement of experimental research in the laboratories entrusted to his guidance at Trinity College. The scholarship would be attached to the department of experimental physics in the College, and would. enable promising students to pursue investigations which, for want of means of immediate support, might otherwise have to be relinquished. Prof. Fitzgerald's marvellous faculties and noble character are so well known and appreciated among scientific men that it is almost unnecessary to urge the claims of the object to their attention. We have confidence that the response to the appeal for funds will be sufficient to provide an adequate endowment for the scholarship it is desired to establish. Subscriptions should be sent to one of the honorary treasurers, Prof. D. J. Cunningham, F.R.S., or Dr. H. H. Dixon, Trinity College, Dublin.

A COMMITTEE has recently been appointed by the Institution of Civil Engineers, with the support of the Institutions of Mechanical Engineers and Naval Architects and of the Iron and Steel Institute, to consider the advisability of standardising the various kinds of iron and steel sections, and, if found advisable, then to consider and report as to the steps which should be taken to carry such standardisation into practice. The committee is composed as follows:-Mr. James Mansergh, Sir Benjamin Baker, K.C.M.G., Sir John Wolfe Barry, K.C.B., Sir Frederick Bramwell, Bart., Sir Douglas Fox, Mr. G. Ainsworth, Mr. William Dean, Mr. A. Denny, Mr. J. Allen McDonald, Mr. E. Windsor Richards, Mr. James Riley, Prof. W. C. Unwin, F.R.S., and Dr. J. H. T. Tudsbery (hon. secretary). Mr. Leslie S. Robertson, of 28, Victoria Street, S.W., has been appointed secretary to this committee, which has already commenced its work by taking evidence tendered by engineers, manufacturers and contractors bearing upon the subject of the inquiry.

The Société des Amis des Sciences physiques et mathematiques at Poltava, Russia, is making arrangements to celebrate the centenary of the birth of Michel Ostrogradsky at Poltava on September 12-25 next.

THE following gentlemen have been elected to fill up vacancies in the list of foreign members of the London Mathematical Society :--Prof. Ulisse Dini, Pisa ; Prof. Georg Cantor, Hallea-Saale ; and Prof. David Hilbert, Göttingen.

THE Berlin correspondent of the Times announces that an office has been opened in Berlin in order to co-operate in the preparation of an international catalogue of scientific literature. Dr. Oscar Uhlworm, chief Royal librarian, has been appointed to direct the work of the office.

THE Royal Horticultural Society will hold an exhibition of lilies at their Chiswick Garden, on Tuesday and Wednesday, July 16 and 17 . On July 16 a conference on lilies will also take place in the Garden. The chair will be taken by Mr. H. J. Elwes, F.R.S., who will deliver an opening address on lilies discovered or brought into cultivation since the issue of his monograph on the subject. 